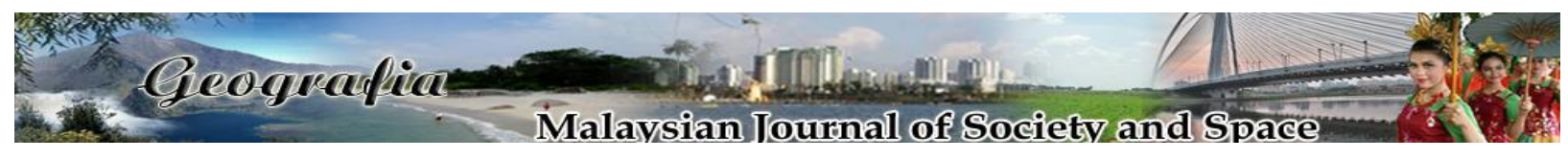

\title{
Application of GIS for evaluation of ethnic fault lines of Karachi
}

\author{
Imran Khan ${ }^{1}$, Salma Hamza², Farkhunda Burke ${ }^{1}$, Syed Nawaz-ul-Huda ${ }^{3}$, \\ ${ }^{1}$ Department of Geography, University of Karachi, Karachi, Pakistan \\ ${ }^{2}$ Department of Earth and Environmental Science, Bahria University, Karachi Campus, Pakistan \\ ${ }^{3}$ DAWN GIS, Geospatial, Statistical, Research \& Analysis Division, Dawn Media Group \\ Correspondence: Syed Nawaz-ul-Huda (email: nawaz_huda@hotmail.com)
}

Received: 24 October 2019; Accepted: 06 August 2020; Published: 29 November 2020

\begin{abstract}
Karachi, megapolis has witnessed numerous massive homicide incidents waves through the ages. More than ten thousand persons were murdered during 2009-2017. Being a largest cosmopolitan and commercial city of Pakistan, Karachi has a variety of ethnic groups clustered into a highly variegated number of ethnic political groups who on the slightest pretext entangle clashes and head on collisions. Homicide, a primeval crime has been constantly increasing globally with varying spatio-temporal fluctuations depending on level of development of countries, which influences the socio-cultural and political environments of societies. There are various studies on crimes in Karachi but none of them have evaluated their ethnic jolts line with reference of geodemography. The study is aimed to facilitate concerned authorities, policy makers and scholars towards designing crime elimination guidelines and policies for the most politically, economically and socially strategic hub of the country. Data limitations were experienced during the work although ground truthing with the help of GPS was conducted for location of homicide hotspots and IDW techniques were employed for accuracy of spatial analysis. The result has identified the heart of the city as the most sensitive homicide zone, though 2017 revealed substantial decrease due to the operation initiated in September 2014 by newly elected federal govt. The lucrativeness of Karachi, has favored it as a haven Routine Activity Theory with fluctuating volumes of homicides concentrate and trajectories through 2009 until 2017. The trajectories being guided by social, ethnicity, magnified by ignorance of the minimal existent socioeconomic policies through official guardian, manifested along the ethnic fault lines.
\end{abstract}

Keywords: Ethnic fault lines, geography and crimes, homicides, Karachi, spatio-temporal analysis

\section{Introduction}

Pakistan's largest city, Karachi, witnessed massive homicide incidents between 2009 and 2017. More than ten thousand persons were murdered during this period. According to reported news, 
homicides maybe considered as epidemiologic because Karachi's rate was more than 09 homicides per 100,000 population during 2009-2017 (Khan et al., 2019). Pakistan Bureau of Statistics reports indicated higher homicide rates than other populous cities of Pakistan (GoP, 2017). Globally, Pakistan falls among the top 10 highly ranked homicide incidence (Table 1).

Subsequent to the 9/11 incident in the USA and its attack on Afghanistan, government of Pakistan took several measures for improvement of law and order condition in the country because during that era numerous Pakistanis suffered loss of lives in addition to incurring huge financial losses (NACTA, 2017). After the cold war, the US designed militant groups, disassociated from their protectors, gained power across Pakistan-Afghanistan border areas which changed the political scenario (Billion, 2001). USA's 2001 attacks on Afghanistan instigated large number of militant groups who became allies of NATO forces, to operate against Pakistan (Khattak, and Mushtaq, 2015; Khan, 2013). Bomb blasts, target killings based on linguistic, religious conflicts and suicide attacks as well as drone attacks penetrated from the border districts into major urban centers of Pakistan (Khan, 2011; Connell, 2010). Several military operations were launched against militants in Pakistan since the 9/11 incident, till 2016 (Javed, 2017; Johnston, 2016).

Table 1. Top 10 ranked countries by homicide incident

\begin{tabular}{ccc}
\hline Rank & Country & Homicide case \\
\hline 1 & Brazil & 50108 \\
2 & India & 43355 \\
3 & Nigeria & 33817 \\
4 & USA & 14827 \\
5 & Colombia & 14670 \\
6 & Pakistan & 13846 \\
\hline
\end{tabular}

Source: UNODC, 2013

The general election 2008, witnessed replacement of army regime by civilian authority. After more than a decade, the coalition government weilding the rein of the country, tried to suppress their rivals, as a result of which several ethnic based political groups faced clashes and head on collisions with each other, especially in Karachi. Due to engagement of security forces against terrorism, violence increased in the highly urbanized city.

The province of Sindh, the second largest in terms of population and third in terms of area has a variety of ethnic groups especially in its provincial headquarter, Karachi (Miandad et al., 2015). Karachi contributes 33 per cent share to total population of the province as observed in Census 2017, with two main divisions of population i.e. urban and rural. The financial hub, Karachi is not only known as the revenue of engine of Sindh but Pakistan has also been witnessing spiraling trends in terms of population. Due to availability of job opportunities, migrants swarm in from various parts of the country, thus creating vast differences between urban and rural politics, and the current situation is proving vulnerable for rural based political parties as a result of which they are anxious about the decreasing electoral seats from rural to urban areas, which may result in weakening their various ethnic groups and strongholds in Sindh (Gazdar \& Mallah, 2013; Javaid \& Hashmi, 2012).

In 1998 census, Karachi had 9856918 population which increased to 16054988 in the 2017 Census. According to the study of Mercer and Price Water House Coopers, with gross 
domestic product (GDP) of \$78 billion in 2009 and projections of around $\$ 193$ billion in 2025, Karachi ranked topmost among the four provincial capitals of Pakistan. The city comprises on 06 districts with largest contribution to international trade of Pakistan, including a huge share of its national tax revenues. Law and order have been distinctive issues of Karachi since couple of decades (Gazdar \& Mallah, 2013). Ethnic riots, political turf wars, state actions against opponent political parties, sectarian killings, perpetration of gang wars and terrorism have been key causes of homicides in the study area. Major ethnic groups in the city are Mohajirs (Urdu speaking), Pakhtuns (Pashtu speaking), Baloch (Balochi speaking), Punjabis and Katchis \& Memons (Punjabi and Gujrati speaking respectively) (Miandad et al., 2015). According to history, the first notable conflicts erupted between Mohajirs and Pakhtuns in 1965 which culminated in the development of ethnic depression in the city.

After 1979, Pakistan played a crucial role under the guidelines of the USA and its allies against USSR on the soil of Afghanistan and dispatched groups of young fighters who came from the Middle East, along with Pakistani tribals from low profile areas under the banner of Jihad (Islamic religious war). A large volume of displaced Afghans moved to Pakistan as refugees, among whom a large multitude settled in the urban areas of Karachi, encroaching on both public and private lands. They came with weapons and drugs, as a result of which heavy ammunition and narcotics where introduced into Karachi. In addition, sectarian violence was also promoted by the Afghan war, because Saudi funded jihad focused on expansion of Saudi religious ideology into Pakistan. The jihadi elements encountered opponent sects; the Shia sect being prominent as a result of which sectarian fault lines appeared in the city. Such situations activated behavioral magma between two groups due to increase of both ethnic as well as religious temperature, most prominently between Mohajirs and Pakhtuns. In 1984, Mohajirs supported a newly created political party known as the Mohajir Qoumi Movement (MQM) for protection of their rights and the Awami National Party (ANP) attracted the Pakhtuns, which brought to light the factual indication of differences between the two ethnic groups. After the 1986 massacres, Mohajir and Pakhtun settlements were isolated from each other and their bordering areas became active ethnic fault zones.

In Sindh, the Pakistan Peoples Party (PPP) recognized as the Sindhi nationalist party was desirous of expelling all migrants who came from British India subsequent to the Indo-Pak division. In 1971, when the PPP for the first time came into power and formed its government, riots against the Mohajir community occurred in interior Sindh, as a result of which, friction between both ethnic groups heightened through the years leading to escalation of hatred. The PPP government also introduced quota system (distribution of government jobs based on urban/ rural population, antagonist to merit culture) for support of their lingual groups in Sindh. This system also aggravated Sindhi-Mohajir relationship in the study area, thus reinforcing the major ethnic fault lines in Karachi. 


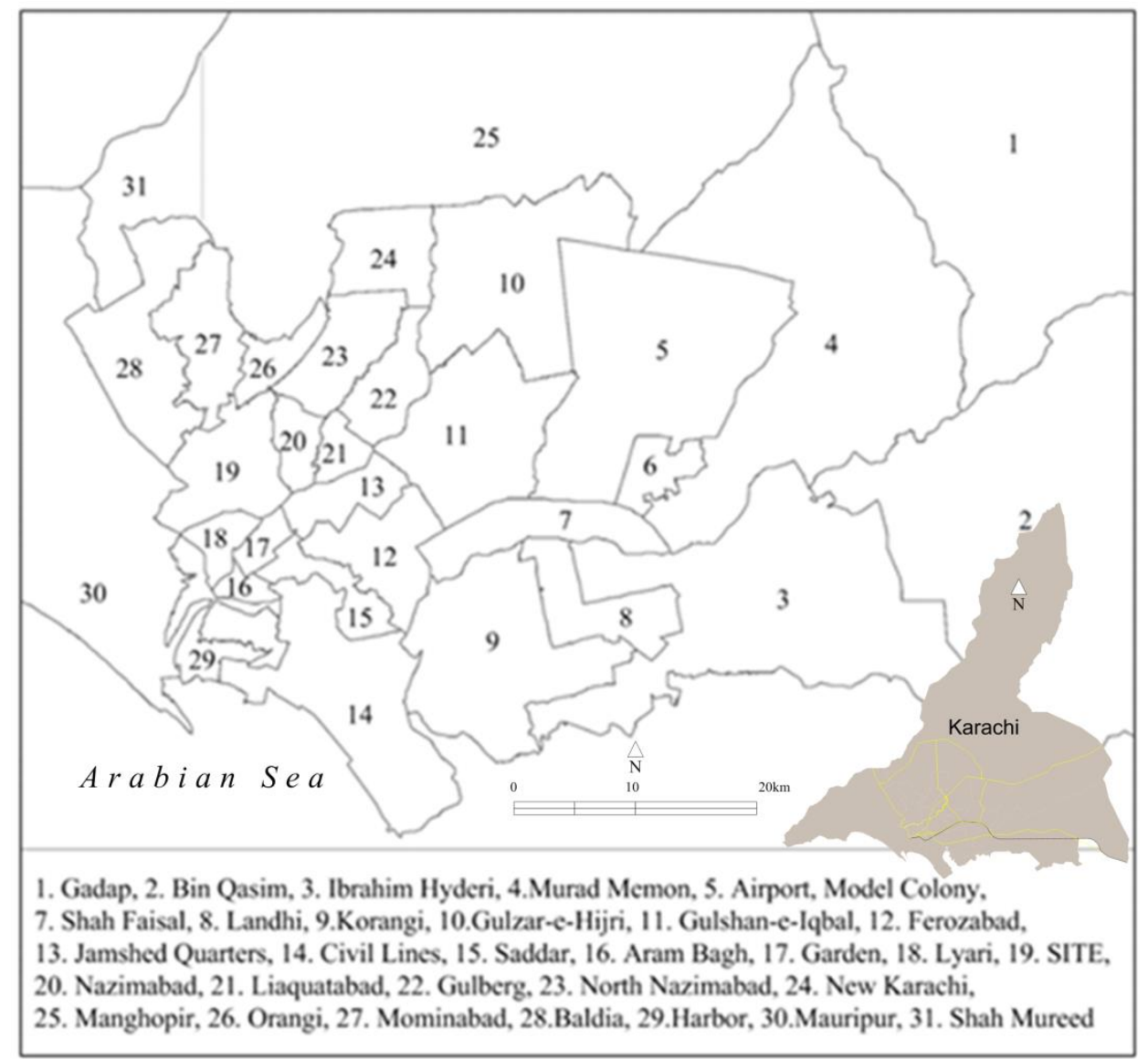

Figure 1. Location of the study area and study units

Karachi has a variety of ethnic groups by virtue of being Pakistan's largest commercial hub as a result of which several ethnic based political groups faced clashes and head on collisions with each other. Various studies with reference to crimes in Karachi have been made but none of them evaluated ethnic jolts line with the reference to spatial geo-demography. This study on spatial pattern of crimes can be used by government to minimize number of homicide incidents. The hypotheses of the present study is that spatial concentration of homicides during 2009-2017 occurred around ethnic fault lines, as also that its fluctuations indicate, incompetency of city guardian.

The study is aimed to provide help to concerned authorities and policy makers for designing of crime elimination or minimization policies in the study area. In addition, the study will also be an aid for scholars interested in study of geo-demographic factors and their influence on crime escalations and reductions in different urban areas of the country. The main objective of the present work is the identification of homicide tracts and their concentrations; demarcation of most sensitive areas in the jurisdiction of the existing sub-divisions through development of geocoded homicide database with the help of IDW grid analysis and to assess the horrifying intensity of homicides on population. 


\section{Literature review}

Crime analysts introduced micro level geographic study of crimes in the late 1980s for the identification of hotspots (Weisburd \& Green, 1994; Weisburd et al., 1992; Sherman et al., 1989; Evans \& Herbert, 1989; Pierce et al., 1988; Felson, 1987). The term 'criminology of place' was recognized by Sherman et al. (1989), and this gained popularity. Several scholars further extended their studies towards greater accuracy and more minute evaluations in the field of spatial criminology. Studies of crimes, therefore diversified into ethnic fault lines, congested trade centers, shopping zones, community centers and parking lots etc. (Curman et al., 2015; Weisburd \& Amram, 2014; Moris, 2013; Sherman et al., 1989).

Studies of violence and crime were interesting subjects for scholars for several decades (Roger, 1989). Due to increasing trend of urbanization in the late 1990s, the issue of violence and crimes had taken on particular significance especially in the context of urban poverty and inequality (Vanderschueren, 1996; Pinheiro, 1993). In many countries undergoing democratization, periods of political conflict, 'everyday' or endemic violence had not abated (Berdal \& Keen, 1997; Poppovic \& Pinheiro, 1995), and Karachi with its ethnic conflicts was also recognized as such since the late ' 90 s to the early decade of the $20^{\text {th }}$ century as acutely painful with reference to homicide incidents (Gazdar \& Mallah, 2013).

Mcilwaine (1999) also highlighted on political, economic and social issues which could have impact on violence and crimes in developing countries. He discussed violence and crime as development issues in the field of geography and analyzed their various aspects with reference to their geographical perspectives. Different disciplines analyzed the causes of crimes at discrete levels, common among which were structural, institutional, interpersonal and individual (Moser et al., 1999; Turpin \& Kurtz, 1997). Generally, various theories related to violence and crime emphasized more on the individual level due to psychological or physiological, tendencies, or genetic, culminating in violent behavior (Robertson \& de Kiewit, 1998). Also, some evidence of thrust towards the epidemiological approach was evidenced in the work of Zwi and Ugalde (1989), and Reeler (1998), as well as political scientists who proved that inequality and improper application of criminal justice system were the major causes of violence and crime eruption in any culture and society (Keane, 1996).

Most of these approaches were utilized in the context of developing countries in some shape or form due to escalating rates of crimes and homicide incidents. Moser et al. (1999) focused on impact of political intrigues on crimes and a developing country like Pakistan falls very much in line with their examples because political conflicts are one of the significant causes of violence and crime in the country. Unstable political processes, especially create spaces for armed groups, militancy and paramilitary activities as well as political assassinations (Ali, 2012; Cockayne, 2010; O'Connell, 2010; Acharya, 2009; Grare, 2007; Brandl, 2003).

The geographic concentration of crimes and place-based policing strategies cover the perspective of environmental criminology focusing on the occurrence of criminal occurrences and the immediate circumstances in which they happen (Wortley \& Mazerolle, 2008). The Routine Activities (Cohen \& Felson, 1979), Rational Choice (Cornish \& Clarke, 1986), Crime Pattern (Brantingham \& Brantingham, 1993a; 1993b) and Social Disorganization theories etc. have significant relevance to crimes in geographic units (Weisburd et al., 2012).

Several scholars inspired by the Spatial Concentrations of Crime and Routine Activity theories, further identified that convergence occurred at discrete locations and they explained why it occurred on specific street segments (Andresen \& Malleson, 2011; Groff, Weisburd \& 
Yang, 2010). Pereira et al. (2017), provided significant guidelines towards the comprehension of homicide spatial patterns and concentrations with reference to the Brazilian city of Recife. Reviewed literature has revealed death of studies regarding spatial patterns of crimes especially through employment of location based methodologies supportive for providing help for formulating homicide control initiative policy. The present study, employing location based analysis can be contribute towards investigation for crime control in locations of concentrations as well as in comprehending the spatial homicide patterns in Pakistan's most populated city, Karachi with supportive and extended geographical reasons. The period of study i.e. 2009-2017, recorded high homicide rates, even in the context of other cities of Pakistan. Launching of the Zarb-e-Azab (Pakistan Army Operation) in 2013, against terrorism, played a vital role in reduction of homicides, consistent with the national crime reduction policy.

\section{Research method}

For the present study, homicide data was collected from Karachi Police Office (KPO), which included their spots of occurrence along with dates for the period between 2009 and 2017. This period was considered because 2009 was the second year of the newly elected provincial government subsequent to the general elections which completed 05 years of its term, culminating in the 2013 general elections. Subsequent to collection of homicides data in accordance to their addresses provided by the Central Police Office, the researchers visited those locations and collected coordinates data through Global Positioning System (GPS) for the preparation of geo-coded crimes dataset. In the second step, all geo-coded information was arranged in the lowest hierarchy i.e., the sub-division. For identification of homicide clustering spatial correlation technique with the help of Arc GIS 10.2 was applied. The research methodology is elaborated in Figure 2. According to provided data 548,495, 1,705, 2,258, 2,062, 1,803, 915,526 and 450 killings, respectively were recorded for the years 2009 until 2017. Other data related to ethnicity by language at Census Blocks Level was obtained from publications of the Pakistan Bureau of Statistics.

\section{Study Unit for Spatial Analysis}

The spatial units used for analyzing the heterogeneity of homicides in Karachi city were subdivisions, numbering 31 as shown in figure 1. Sub-division administrative units are headed by Assistant Commissioners appointed by the provincial government. Through GPS located cluster, IDW technique employed for accuracy of the research, the heart of the city emerged as the most sensitive homicide zone obtained from GIS database of crimes, which were developed for the present study (Huda et al., 2013; Huda et al., 2011; Briggs, 1974; Kurtzman \& Kadmon, 1999).

Curman et al. (2015) worked on street segments using Weisburd et al.'s (2004) trajectory method. The present work having focused on sub-divisions, however, has traced temporal trajectories of homicide concentration areas, with some chronic population spots revealing improvements, while some sub-divisions e.g. Gadap with least population, in addition to some high security areas like Harbour and Airport, also revealing safer conditions. 


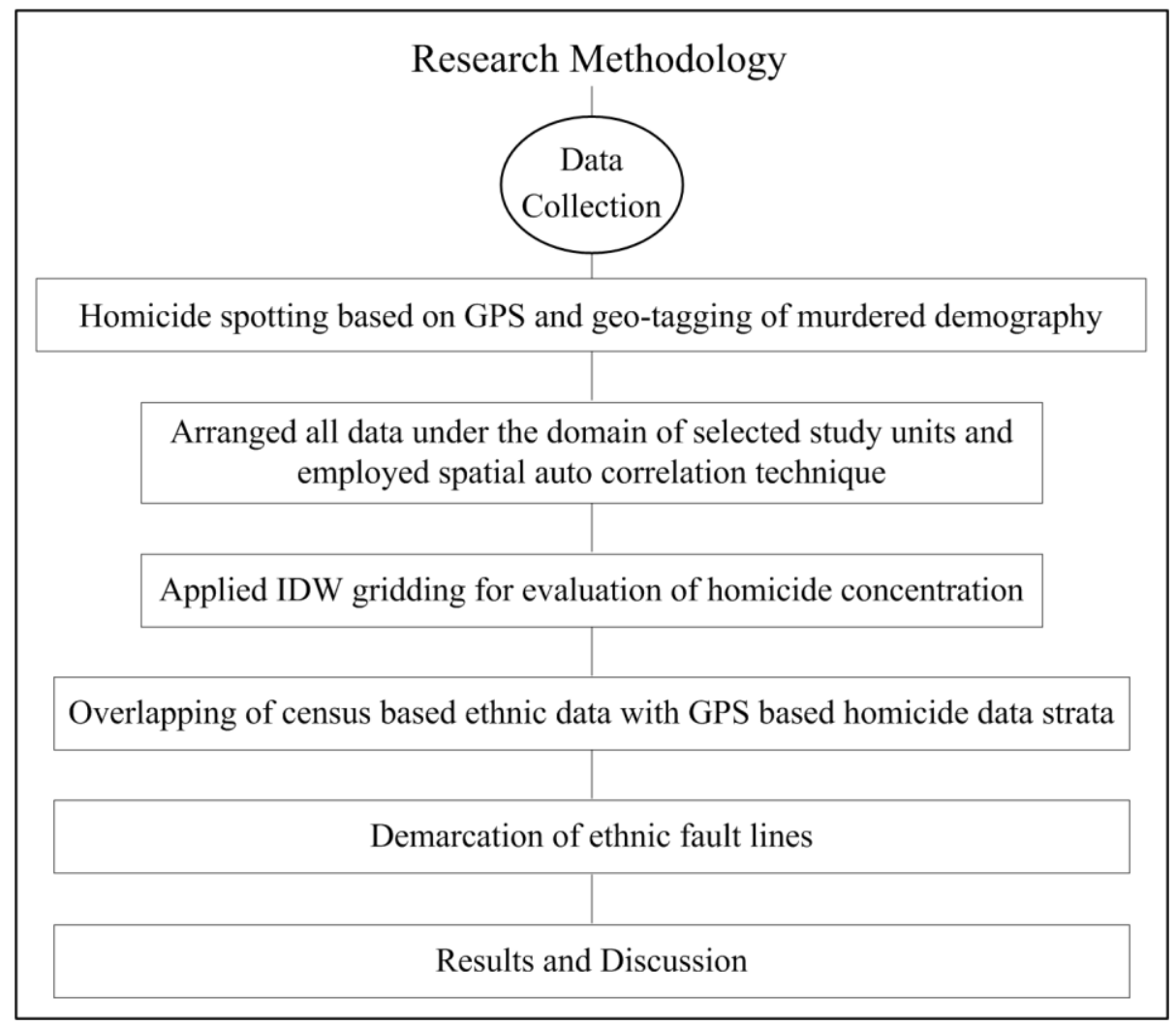

Figure 2. Research methodology framework

\section{Results and discussion}

This study of homicide trends has highlighted the severity of this annihilative dimension among all crimes; the killing of populace being more heinous than all other crimes, as human life is the most precious asset on earth. In 2009, a homicide rate of 0.55 per 1,000 population indicated its severity in the Mega City. In 2010, this ratio dropped to -0.06, while in 2011 it once again shot up to 01.71 per 1,000 persons. In terms of percentages, this increase rate was $244.44 \%$ compared to that in 2010, while in 2012 the homicide ratio increased by $32 \%$ with a rate of 2.25 homicides per 1,000 population in comparison to the previous year. The ratio marginally decreased to 02.06 in 2013, and henceforth to 01.82, 00.92, 00.53 and 00.45 respectively between 2014 and 2017. The average homicide ratio from 2009 until 2017 was 01.20 persons $/ 1,000$.

\section{Homicide Concentrations 2009-2017}

The present study is based on homicide incidence between 2009 and 2017. Figure 3A, depicts homicide concentration scattered in various parts of the study area having recorded 550 deaths in 2009, Aram Bagh recording highest, due to massive explosion on a procession of the Shia sect during the sacred month of Ashura on M.A. Jinnah road, followed by sub-divisions Gulzar-eHijri, Korangi, Model Colony, Gulshan-e-Iqbal, SITE, Ibrahim Hyderi, North Nazimabad, New Karachi and Shah Faisal. 
In 2010 (Figure 3B), the concentration moved towards the northern part where the place Kati Pahari in Orangi was seriously damaged due to ethnic violence. This location has been a very active fault line because two major ethnic groups, Mohajirs and Pakhtuns share 50:50 ratio of the land and population concentration. Geospatial analysis of death tolls of 2010 revealed 41 killings. Figure 3B shows Orangi (Kati Pahari) with top rank, while Gulshan-e-Iqbal ranked second, being another sectarian plate between Mohajirs and Pakhtuns, which recorded an increase of killing from 30 to 35. The 9/11 incident witnessed escalation of terrorism in Pakistan. Sub-division Civil Lines recorded 32 killings in a suicide bomb blast at Crime Terrorism Department (Dawn, 2010). SITE sub-division death toll indicated another ethnic fault active zone due to 30-31 killings in 2009-2010. With reduction of killings from 31 to 28, the situation in Korangi sub-division somewhat ameliorated, as also in Aram Bagh which shared fourth last rank, with reduction in severity of homicides. On the contrary, Saddar and Ferozabad revealed worsening of homicide scenario with an increase from 08 to 09 and 22 to 27 killings i.e. $25^{\text {th }}$ and $24^{\text {th }}$ ranks to $9^{\text {th }}$ and $6^{\text {th }}$ ranks respectively between 2009 and 2010.

Figure 3C depicting the 2011 homicide situation with 1,705 killings reveals a horrifying situation in comparison to that in 2010. Kati Pahari and adjacent areas recorded nearly 200 deaths during the year. The second, long belt extending from Lyari to southern portions of Nazimabad, Liaquatabad and Jamshed Quarters sub-divisions reveals that this plate annihilated more than 300 humans due to Urdu-Balochi temperature raise fuelled by MQM-PPP conflicts. Some micro ethnic conflicts were located at New Karachi-North Nazimabad border, among which Nagan Chowrangi, Gulshan-e-Iqbal, Abul Hasan Isphani Road were seriously affected due to sectarian killings.

Violence intensity is conspicuous in Figure 3D which represents the 2012 scenario when the lava of hate quantum erupted and ravaged around the previous homicide areas. More than 700 souls were annihilated due to the fatal shake of Lyari and Orangi plates. A sectarian jolt at Abul Hassan Isphani Road also saw lethal sect conflicts and more than 50 person lost their lives there during the year. Some other micro plates showed ethnic intensity, among which Baldia, Model Colony and Surjani-New Karachi borders were prominent.

Figure 3E, depicts 2013 recorded homicides, when the Lyari plate was continuously active, while Gulzar-e-Hijri and Orangi preceded. Fatally intense jolts occurred in Lyari and Garden sub-divisions which annihilated 244 souls, while Gulzar-e-Hijri recorded a spiking 179 homicides. Orangi plate also observed lethal shock due to 108 killings. September 14, 2013 was a decisive day when the Prime Minister of Pakistan ordered actions against homicides and gave special powers to federal law enforcement agencies under the banner of Karachi Operation. As a result, the rate of homicides decreased due to detention of a number of culprits, while several goes underground. The Karachi Operation somewhat cooled the temperature. Figure 3F, depicts Lyari and Orangi Plates as continuously active; their aftershocks affecting their neighborhoods. 


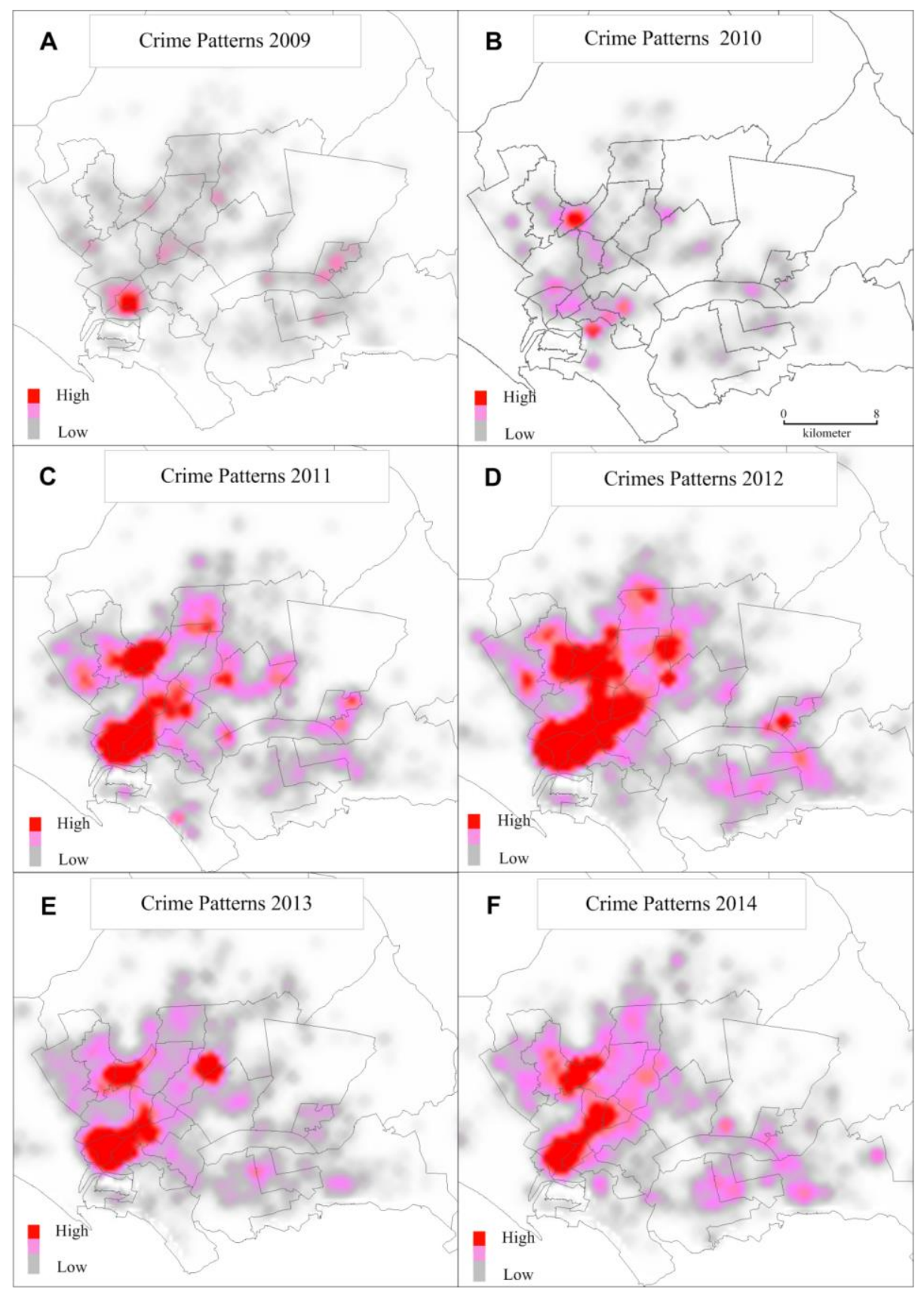

Figure 3. Crime pattern between 2009 and 2014

Figure 4A, indicates somewhat settling of the volatile situation at the Lyari Plate, but Gulzar-e-Hijri plate faced another upheaval, ensued by horrible homicides due to sectarian terrorism. Overall homicides, however portrayed decreasing trends in 2015. Figure 4B, depicts partial stability of ethnic fault lines (areas where several lingual groups clustered in pocket form and separated through main streets or natural features as hillocks, referred here as ethnic fault lines) due to the Karachi Operation as a result of which the study area witnessed fewer casualties, nevertheless, still persistent due to the weak administrative system.

Figure 4C, highlights homicides situation as having reversed with reference to the 2009 picture. Figure 4D depicting the overall homicide scenario during the entire study period 2009- 
2017 portrays widespread disturbance in terms of lethal incidents, with most thickly populated settlements having faced a terrible situation, prominent among them being parts of the old city area i.e. Lyari, Garden \& Old Golimar; Orangi, Kati Pahari, Bukhari Colony, Banaras \& Qasba Colonies and Mominabad; Liaquatabad, Abul Hassan Isphani and Sohrab Goth; Malir (Sahibdad Goth, Saudabad \& Jaffar-e-Tayyar Society), Landhi (Muzaffarabad \& Majeed Colony) and Baldia, as core ethnic killing areas. The second strata was comprised on areas adjacent to the core, except Landhi, Korangi and some parts of Shah Faisal sub-divisions because these were repercussion sites of core death killing areas.

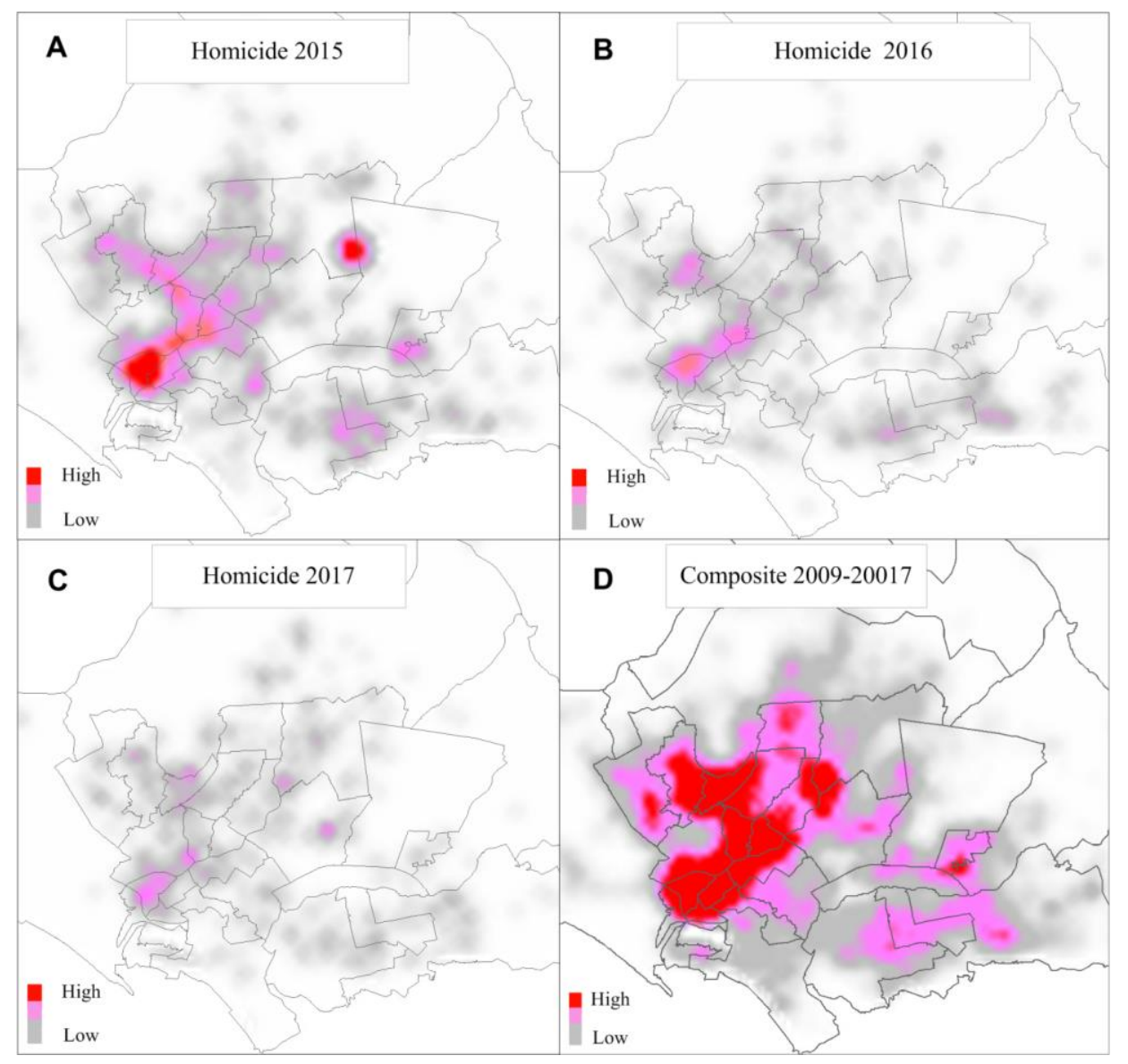

Figure 4. Crime pattern during 2015-2017 and composite 2009-2017

Figure 5, depicts the identified active ethnic plates demarcated on nearly a decade's record of homicides data (2009-2017) and provides strong evidence regarding existing active ethnic fault lines. Following are the homicide plates:

Plate 1. Lyari/Old Golimar Plate - Focused on Lyari, with northern extension into SITE, Nazimabad and south easterly into Jamshed Quarters, large part of Garden, Harbour and a very small part in Aram Bagh (Old Golimar is located in SITE).

Plate 2. Orangi Plate - Centered on Orangi, with extensions into Mominabad and a narrow strip in North Nazimabad.

Plate 3. Sohrab Goth/Abul Hassan Plate - Centered on Gulzar-e-Hijri with extensions into Gulshan-e-Iqbal, Gulberg and New Karachi, Sohrab Goth and Abul Hassan Isphani being focii of killings. 
Plate 4. Malir Plate - Centered on Murad Memon extending into Model Colony and Shah Faisal, commonly known as Malir.

Plate 5. Quaidabad/Dawood Chowrangi Plate - Ibrahim Hyderi, focus of killings being in Quaidabad and Dawood Chowrangi, and

6- Baldia Plate - Focussed on a small part of Baldia.

The first 3 being major, highly active plates while the remaining 03 being less active plates. The common feature of all these plates being, homicides due to ethnicity issues; sectarian being an additional cause in $3^{\text {rd }}, 4^{\text {th }}$ and $6^{\text {th }}$ plates while gang war being an additional cause of killings in the $1^{\text {st }}$ plate and land grabbing in the $5^{\text {th }}$. The piegraphs in figure 5 reveal that Urdu speaking dominate in most of the plates, highest being $43 \%$ in plate 03 , followed by $40 \%$ in plate $2 ; 35 \%, 32 \%, 23 \%$ and $20 \%$ in plates 04,06 and 05 respectively. Highest percentage of Pashtun i.e. $30 \%, 24 \%$ and $22 \%$ are conspicuous in plates 05,06 and 02 , while Baloch percentage is highest in plate 1 .

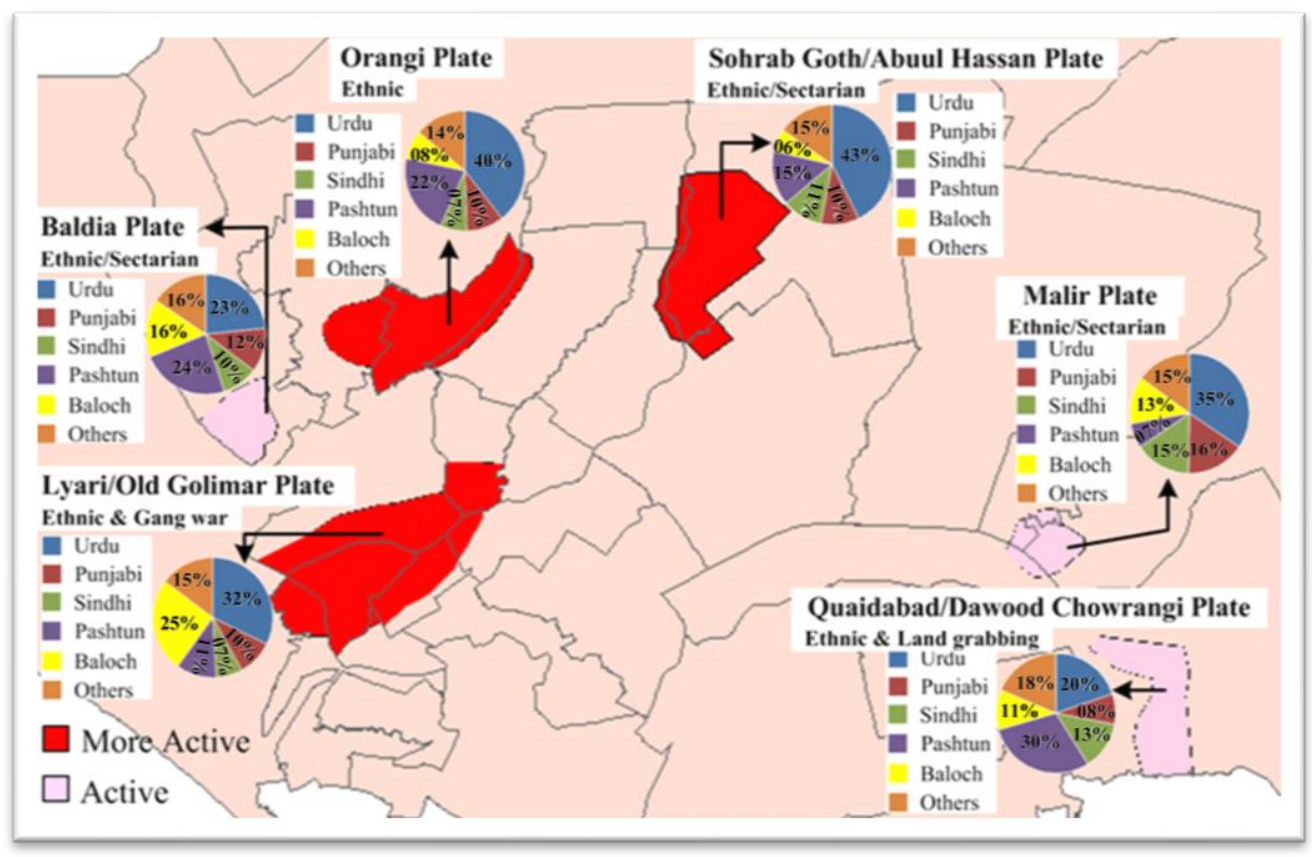

Figure 5. Map depicts ethnic fault lines in the study area

Ethnic clashes have been rampant in the city due to presence of multifarious groups of population of varying ethnic groups, notable among them e.g. Sindhi, Balochi and Punjabi being mainly sons of the soil; Urdu and Pashtun being a mixture of this type along with migrants. Urdu speaking migrants mostly being 72 years old, since the time of partition; while Pashtun includes migrants in Karachi from Balochistan subsequent to the Quetta Earthquake in 1935, and from Afghanistan subsequent to the wars with Russia and USA. Others include Hazaras, Seraikis, Memonis, Katchis, etc.

Sectarian killing in the city have been mainly due to killings of Shias during their most holy month of Ashura. Land grabbing, though politically supported in the whole city, is notably conspicuous in plate 05 , mainly through connivance with powerful political parties; same being the case with gang wars prevalent all over Karachi but most notable in Lyari, which is dominated 
by Balochis and Makranis who were wonderful sportsman at one time, but due to lack of facilities became gangsters.

\section{Conclusion}

The present work having focused on sub-divisions, however, has traced temporal trajectories of homicide concentration areas, with some chronic population spots revealing improvements, while some sub-divisions e.g. Gadap with least population, in addition to some high security areas like Harbour and Airport, also revealing safer conditions. Political stability is essential for provision of security to life and property of citizens. The study, however has limitations with reference to analysis of reported homicides because the number of unknown/ ascertain cases are remarkably high, which should be markedly reduced and remarkably improved for more reliable assessment, hence appropriate provision of quality and quantity security to the tax payers of the city, at least for the security of their lives which is a one-time gift from God. The foregoing account has highlighted the spatio-temporal fluctuations of homicides in the megapolis, Karachi giving valid explanations of shifting concentrations.

At present, Karachi comprises 80 percent of the country's literate population divided into lingual units; the basic reasons for crime and violence being inequality, injustice and political affiliation based administrative government extant from British colonial system. Life safety and prosperity can only be done through assurance and protection of individual empowerment. Although, the administrative units have ensured to some extent resources based revenue distribution but have failed in fulfilling their duty of democracy. Thus, encroachments and organized crimes are rampant in the study area. Land grabbers are inherent in the political setup and protected under the administrative umbrella. Subsequent to the 1979 Afghan war, Karachi faced massive encroachment on both public and private lands. Afghan camps provided shelter to land grabbers because the native and Pro-Afghan fighters easily settled down and no body from among the local population or the government administration dared or bothered to stand against them. Some religious based political parties also completely supported their political setup in encroached areas. Interestingly, all above mentioned facts depict that competent authorities neglected and violated their role of guardian in the country. This situation having created great differences in terms of socioeconomic conditions between encroached and planned societies, the debacle can only be overcome through the pursuance of rule of law without discrimination among ethnic groups; support of democratic approach in the administrative systems and ensurance of empowerment of local government. The present study also emphasizes the need for reshaping of the city as per demands of the quality of life ideology.

\section{References}

Acharya, A., Bukhari, S. A. A. S., \& Sulaiman, S. (2009). Making money in the Mayhem: Funding Taliban insurrection in the Tribal Areas of Pakistan. Studies in Conflict \& Terrorism, 32(2), 95-108. https://doi.org/10.1080/10576100802628314

Ali, Z. (2012). Violence in Karachi; Is It political, ethnic or religious conflict? Pakistaniaat: A Journal of Pakistan Studies, 4(3), 78-83. 
Andresen, M. A., \& Malleson, N. (2011). Testing the stability of crime patterns: Implications for theory and policy. Journal of Research in Crime \& Delinquency, 48(1), 58-82.

Berdal, M. and Keen, D. (1997). Violence and economic agendas in civil wars: Some policy implications. Millennium: Journal of International Studies, 26(3), 795-818.

Billion, P.L (2001). The political ecology of war: Natural resources and armed conflicts. Political Geography, 20, 561-584.

Braga, A. A., \& Weisburd, D. (2010). Policing problem places: Crime hot spots and effective prevention. Oxford University Press on Demand.

Braga, A. A., Hureau, D. M., \& Papachristos, A. V. (2011). An ex post facto evaluation framework for place-based police interventions. Evaluation review, 35(6), 592-626.

Brandl, S. G. (2003). Back to the future: The implications of September 11, 2001 on law enforcement practice and policy. Ohio St. J. Crim. L., 1, 133.

Brantingham, P. L., \& Brantingham, P. J. (1993a). Environment, routine and situation: Toward a pattern theory of crime. Advances in criminological theory, 5(2), 259-294.

Brantingham, P. L., \& Brantingham, P. J. (1993b). Nodes, paths and edges: Considerations on the complexity of crime and the physical environment. Journal of Environmental Psychology, 13(1), 3-28.

Briggs, I. C. (1974). Machine contouring using minimum curvature. Geophysics, 39(1), 39-48.

Cockayne, J. (2010). Crime, corruption and violent economies. Adelphi Series, 50(412-413), 189-218. https://doi.org/10.1080/19445571.2010.515156

Cohen, L. E., \& Felson, M. (1979). Social change and crime rate trends: A routine activity approach. American Sociological Review, 44, 588-605.

Curman, A. S. N., Andresen, M. A., \& Brantingham, P. J. (2015). Crime and place: A longitudinal examination of street segment patterns in Vancouver, BC. Journal of Quantitative Criminology, 31, 127-147.

Evans, David J., \& David T. Herbert. (1989). The Geography of Crime. London: Routledge.

Felson, M. (1987). Routine activities and crime prevention in the developing metropolis. Criminology, 25, 911.

Gazdar, H., \& Mallah, H. B (2013). Informality and Political Violence in Karachi, Urban Studies, 50(15), 3099-3115. https://doi.org/10.1177/0042098013487778

Grare, F. (2007). The evolution of sectarian conflicts in Pakistan and the ever-changing face of Islamic violence. South Asia: Journal of South Asian Studies, 30(1), 127-143.

Groff, E. R., Weisburd, D., \& Yang, S.-M. (2010). Is it important to examine crime trends at a local "micro" level? A longitudinal analysis of street to street variability in crime trajectories. Journal of Quantitative Criminology, 26, 7-32.

Javed, A. (2017). Pakistan counter terrorism policy since Zarb-i-Azab: Challenges and prospects for peace and security. Journal of Politics and International Studies, 3(1), 21-35.

Javaid, U., \& Hashmi, R. S. (2012). Contending Ethnic Identities: An Issue to Pakistan's Internal Security (The case of Karachi). Journal of political studies, 19(1).

Johnston, P. B., \& Sarbahi, A. K. (2016). The impact of US drone strikes on terrorism in Pakistan. International Studies Quarterly, 60(2), 203-219.

Huda, S. N., Burke, F., Anwar, E., Ahmed, I., Miandad, M., \& Azam, M. (2013). Spatial analysis of sulfur dioxide (SO2) concentration in Karachi, Megapolis, Pakistan. Lasbela University Journal of Science and Technology, 2(1), 1-18. 
Huda, S. N., Burke, F., Miandad, M., \& Rana, M. N. (2011). Analysis of national assembly 55rawalpindi franchise: an electoral GIS perspective of Pakistan. The Research Journal of Sciences and Technology, 2(1\&2), 35-48.

Keane, J. (1996). Reflections on violence. London: Verso.

Khan, I., Burke, F., \& Nawaz-ul-Huda, S. (2019). Spatiotemporal Concentration of Homicides in Karachi. Pakistan Journal of Criminology, 11(1).

Khan, H (2013). Pakistan's Contribution to Global War on Terror After 9/11, IPRI Journal, XIII(1), 37-56.

Khan, N. (2012). Between spectacle and banality: Trajectories of Islamic radicalism in a Karachi neighbourhood. International Journal of Urban and Regional Research, 36(3), 568-584.

Khattak, M.R and Mushtaq, M (2015). Pakistan's Counter-Terrorism Strategy (2001-2014): An Analysis, Pakistan Journal of History and Culture, XXXVI(1).

Kurtzman, D., \& Kadmon, R. (1999). Mapping of temperature variables in Israel: A comparison of different interpolation methods. Climate Research, 13(1), 33-43.

Mcilwaine, C (1999). Geography and Development: Violence and Crime as Development Issues, Progress in Human Geography, 23(3), 453-463.

Miandad, M., Burke, F., Nawaz-ul-Huda, S., Ghazi, S., \& Azam, M. (2015). Lingual Distribution of Tuberculosis Patients in Karachi-A Demographic Analysis. Journal of Basic \& Applied Sciences, 11, 74.

Morris, T. (2013). The criminal area: A study in social ecology (Vol. 4). Routledge.

Moser, C. O., \& Shrader, E. (1999). A conceptual framework for violence reduction. World Bank, Latin America and Caribbean Region, Environmentally and Socially Sustainable Development SMU.

NACTA. (2017). National Counter Terrorism Authority Report, Terrorism Decline in Pakistan, Published by NACTA 22 September, 2017.

O'Connell, Mary Ellen. (2010). Unlawful Killing with Combat Drones: A Case Study of Pakistan, 2004-2009. In Simon Bronitt, (Ed.). Shooting to kill: The law governing lethal force in context, Forthcoming, Notre Dame Legal Studies Paper No. 09-43. Retrieved from https://ssrn.com/abstract=1501144

Pereira, D. V., Mota, C. M., \& Andresen, M. A. (2017). The homicide drop in Recife, Brazil: A study of crime concentrations and spatial patterns. Homicide studies, 21(1), 21-38.

Pierce, Glenn L., Susan Spaar, \& LeBaron R. Briggs. (1988). The character of police work: Strategic and tactical implications. Boston, MA: Center for Applied Social Research, Northeastern University.

Pinheiro, P.S. (1993). Reflections on urban violence. Urban Age, 1, 3-4.

Poppovic, M. \& Pinheiro, P.S. (1995). How to consolidate democracy? A human rights approach. International Social Science Journal, 143, 75-89.

Hawksworth, John, Thomas Hoehn \& Anmol Tiwari (2009), "Which are the largest city economies in the world and how might this change by 2025?" in Price Waterhouse Coopers (PwC), UK Economic Outlook November 2009, London, pages 20-34.

Reeler, T. (1998). Epidemic violence and the community: A Zimbabwean case study. Community Development Journal, 33, 128-38.

Robertson, G., \& De Kiewit, S. (1998). Wilderness therapy with militarised youths in traumatised communities. Community Development Journal, 33, 139-44.

Rogers, J.D. (1989). Theories of crime and development: an historical perspective. Journal of Development Studies, 25, 314-28. 
Sherman, L. W., Gartin, P., \& Buerger, M. E. (1989). Hot spots of predatory crime: Routine activities and the criminology of place. Criminology, 27, 27-55.

Sherman, L. W., Gartin, P. R., \& Buerger, M. E. (1989). Hot spots of predatory crime: Routine activities and the criminology of place. Criminology, 27(1), 27-56.

Turpin, J. E., \& Kurtz, L. R. (Eds.). (1997). The web of violence: From interpersonal to global. University of Illinois Press.

Vanderschueren, F. (1996). From violence to justice and security in cities. Environment and Urbanization, 8, 93-112.

Weisburd, D., \& Amram, S. (2014). The law of concentrations of crime at place: the case of Tel Aviv-Jaffa. Police Practice and Research, 15(2), 101-114.

Weisburd, D., Groff, E. R., \& Yang, S.-M. (2012). The criminology of place: Street segmentsand our understanding of the crime problem. New York, NY: Oxford University Press.

Weisburd, D., Bushway, S., Lum, C., \& Yang, S. M. (2004). Trajectories of crime at places: A longitudinal study of street segments in the city of Seattle. Criminology, 42(2), 283-322.

Weisburd, David, \& Lorraine Green. (1994). Defining the street-level drug market. In Doris Layton MacKenzie and Craig D. Uchida. (Eds.). Drugs and Crime: Evaluating Public Policy Initiatives. Thousand Oaks: Sage Publications.

Weisburd, D., Lisa, M., \& Lawrence, W. S. (1992). Contrasting crime general and crime specific theory: The case of hot spots of crime. In Freda Adler \& William S. Laufer (Eds.). Advances in Criminological Theory. New Brunswick, NJ: Transaction.

Wortley, R., \& Mazerolle, L. (2008). Environmental criminology and crime analysis: Situating the theory, analytic approach and application. In R. Wortley, \& L. Mazerolle (Eds.). Environmental criminology and crime analysis (pp. 1-15). London, UK: Willan Publishers.

Zwi, A., \& Ugalde, A. (1989). Towards an epidemiology of political violence in the Third World. Social Science and Medicine, 28(7), 633-42. 